\title{
Pseudomonas pyocyanin stimulates IL-8 expression through MAPK and NF-KB pathways in differentiated U937 cells
}

Wenshu Chai ${ }^{*}$, Jia Zhang ${ }^{2}$, Yan Duan ${ }^{1}$, Dianzhu Pan ${ }^{1}$, Wei Liu' ${ }^{1}$, Ying Li $^{1}$, Xue Yan ${ }^{1}$ and Baiyi Chen ${ }^{3 *}$

\begin{abstract}
Background: Pyocyanin (PCN), an extracellular product of Pseudomonas aeruginosa and a blue redox active secondary metabolite, plays an important role in invasive pulmonary infection. However, the detailed inflammatory response triggered by PCN infection in inflammatory cells (particularly macrophages), if present, remains to be clarified. To investigate the effects of PCN on macrophages, the ability of PCN to induce inflammation reaction and the signaling pathway for IL-8 release in PCN-induced differentiated U937 cells were examined.

Results: It was found that PCN increased IL-8 release and mRNA expression in Phorbol 12-myristate 13-acetate (PMA) differentiated U937 cells in both a concentration- and time-dependent manner by reverse transcription-polymerase chain reaction (RT-PCR) and enzyme-linked immunosorbent assay (ELISA). P38 and ERK MAPKs were activated after 10 min of induction with PCN and their levels returned to baselines after 30 min by Western blotting. It was also found that within 10 min of PCN incubation, the level of $\mathrm{p}-\mathrm{l-kBa}$ in the cytosol was increased, which returned to baseline level after 60 min. Meanwhile, the level of p-p65 was increased in the nuclear extract and cytosol, and maintained high in total cell lysates. The results were further confirmed by the observation that p38, ERK1/2 and NF-KB inhibitors inhibited PCN-induced NF-KB activation and attenuated PCN-induced IL-8 expression in U937 cells as a function of their concentrations. Moreover, it was shown that PCN induced oxidative stress in U937 cells and N-acetyl cysteine, an antioxidant, was able to inhibit PCN-induced IL-8 protein expression.
\end{abstract}

Conclusions: It is concluded that PCN induces IL-8 secretion and mRNA expression in PMA-differentiated U937 cells in a concentration- and time- dependent manner. Furthermore, p38 and ERK MAPKs and NF-KB signaling pathways may be involved in the expression of IL-8 in PCN-incubated PMA-differentiated U937 cells.

Keywords: Pyocyanin, IL-8, U937 cell, p38, ERK, NF-KB

\section{Background}

Pseudomonas aeruginosa ( $P$. aeruginosa), an opportunistic pathogen, causes infections associated with high incidences of morbidity and mortality in immunocompromised hosts. P. aeruginosa colonizes the lower respiratory tract in patients resulting in bronchiectasis, cystic fibrosis, and chronic obstructive pulmonary disease [1-3]. The pathogen has a broad host range, which produces a large

\footnotetext{
*Correspondence: cws1964@aliyun.com; chenbaiyi63@163.com

'Department of Respiratory Diseases, the First Affiliated Hospital of Liaoning

Medical University, Jinzhou, Liaoning, 121001, China

${ }^{3}$ Department of Infectious Diseases, the First Affiliated Hospital of China

Medical University, Shenyang, Liaoning 110001, China

Full list of author information is available at the end of the article
}

number of extracellular products including elastase and alkaline protease, LasA protease, hemolysin, rhamnolipid, and pyocyanin $(\mathrm{PCN})$. These extracellular products alter host cell function and may contribute to disease pathogenesis.

Among recognized virulence factors, the redox-active phenazine PCN, a blue redox active secondary metabolite, plays an important role in invasive pulmonary infection. Early studies have shown that PCN causes multiple effects on human cells, such as inhibition of cell respiration, ciliary function, epidermal cell growth, and prostacyclin release. Furthermore, PCN alters calcium homeostasis, causing damage to human cells. Recent studies have confirmed that PCN can alter the host's immune response and increase IL-1 and TNF- $\alpha$ secretion induced by monocytes. 
PCN can also inhibit the body's specific immune response to clear out pathogens, extend the time limit or prevent the infection of bacterial clearance, and increase secretion of inflammatory mediators in the body that can produce adverse reactions. Studies have also shown that PCN and its precursor, promethazine-1-carboxylic acid, change the host's immune response by adjusting the RANTES [4] and IL-8 levels, and that in a variety of respiratory cell lines and primary cell cultures, PCN stimulation can cause the release of IL-8, IL-1 and IL-6 [5], accompanied by increased levels of IL-8 mRNA. PCN also acts in synergy with IL- $1 \alpha$, IL- $1 \beta$ and TNF- $\alpha$ to induce IL-8 expression in human airway epithelial cell lines [6-8]. In contrast to its effects on IL-8 expression, PCN inhibits cytokine-dependent expression of the monocyte/macrophage/T-cell chemokine RANTES. It is possible that the inhibition could cause inflammation of mononuclear macrophage and $\mathrm{T}$ cell influx to subside.

Alveolar macrophages are significant defense cells and inflammation regulatory cells which switch on multiplicity mediators of inflammation and cytokines and then cause acute lung injury. Although lung macrophages have the capacity to participate in the host response to $P$. aeruginosa, the role of alveolar macrophages in acute $P$. aeruginosa infection has not been clearly defined. The molecular mechanism by which these factors exert their effects is poorly understood. Human medullary system cell line U937 cells share characteristics with monoblasts and pedomonocytes. The human U937 promonocytic cell line was selected as the cell model since it is widely used to study the differentiation of promonocytes into monocyte-like cells [9-11]. Therefore, in this study, U937 cells were induced and differentiated into macrophages with phorbol 12-myristate 13-acetate (PMA) and used to study PCN effects on human macrophages.

Pseudomonas infections are characterized by a marked influx of polymorphonuclear cells (PMNs) (neutrophils) [12]. Increased release of IL-8, a potent neutrophil chemoattractant, in response to PCN may contribute to the marked infiltration of neutrophils and subsequent neutrophil-mediated tissue damage that are observed in Pseudomonas-associated lung diseases [7]. Previous studies by other investigators have identified a Pseudomonas secretory factor with the properties of PCN that increases IL-8 release by airway epithelial cells both in vitro [13] and in vivo [14]. Based on these studies, we examined the effect of PCN on IL-8 release in vitro using the human monocyte model (PMA-differentiated human promonocytic cell line U937) in synergy with inflammatory cytokines. The reasons for specific focus on IL- 8 and nuclear factor$\kappa \mathrm{B}(\mathrm{NF}-\mathrm{\kappa B})$ pathway for IL-8 modulation are that IL-8 is an established enhancer of neutrophil function $[5,6,8]$, while NF- $\mathrm{kB}$ is a transcription factor believed to play a key role in IL-8 expression [15].
Meanwhile, a number of studies have also shown that the mitogen-activated protein kinases (MAPKs, including ERK, JNK and p38) signal transduction pathways mediate a variety of stimulating factors-induced IL-8 expression [4,16-18]. NF- $\mathrm{kB}$ is a ubiquitous pleiotropic transcription factor. Studies have shown that NF- $\mathrm{B}$ activation is a contributing factor for a variety of lung diseases and lung inflammation [19-21]. Pyrrolidine dithiocarbamate, a metal chelator and antioxidant, can inhibit the activation of NF$\mathrm{kB}$ specifically by suppressing the release of the inhibitory subunit Ik-B from the latent cytoplasmic form of NF-kB. Recent studies have indicated that maximal IL- 8 protein expression requires activation of NF- $\mathrm{kB}$ as well as MAPKs [17]. However, the precise relationship between NF- $\mathrm{kB}$ transactivation and MAPK activation remains unclear. In addition, few cellular pathways that are affected by PCN are known. Hence, the present study was designed to testify whether PCN can provoke the activation of macrophages, and whether NF- $\mathrm{KB}$ and MAPKs are involved in this possible process.

\section{Methods}

\section{Chemicals and reagents}

RPMI-1640, fetal bovine serum (FBS), and antibiotics were purchased from GIBCO BRL (Grand Island, NY). Phospho-specific p38 MAPK and p38, and phosphospecific ERK1/2 and ERK1/2 were from New EnglandBiolabs (Bevely, MA). Stocks of the selective p38 MAPK inhibitor SB203580, and stocks of the selective ERK1/2 inhibitor PD98059 were purchased from Calbio-chemBehring (Za Jolla, CA). Phospho-NF-кB p65 (Ser276) antibody was purchased from Cell Signaling Technology (CST, Danvers, MA) and anti-p-IkB- $\alpha$ (Ser32) from Santa Cruz Biotechnology (Santa Cruz, CA) . IL-8 assay kit and TNF- $\alpha$ were purchased from R\&D Systems (Minneapolis, $\mathrm{MN})$. PMA was purchased from Merck Biosciences (San Diego, CA). PMS (phenazinem ethosulfate, molecular formula: $\mathrm{C}_{14} \mathrm{H}_{14} \mathrm{~N}_{2} \mathrm{O}_{4} \mathrm{~S}$ ) was from AMRESCO (Solon, $\mathrm{OH}$ ). NF- $\kappa$ B inhibitor PDTC, PCN, N-acetylcysteine, LDH, SOD, $\mathrm{CAT}$, and MDA assay kits were purchased from Sigma Chemical Co. (St. Louis, MO). All other reagents, unless specified, were purchased from Sigma Chemical Co.

\section{Cell culture and differentiation}

U937 cells were purchased from ATCC (American Type Culture Collection, Rockville, MD) and were cultured at $37^{\circ} \mathrm{C}$ in a humidified atmosphere with $5 \% \mathrm{CO}_{2}$ in RPMI 1640 medium supplemented with $10 \%$ FCS and $50 \mu \mathrm{g} / \mathrm{mL}$ gentamicin, which itself was supplemented with $4.5 \mathrm{~g} / \mathrm{L}$ glucose, $1 \mathrm{mM}$ sodium pyruvate, and $10 \mathrm{mM}$ HEPES. Cell culture was maintained at a density of $1 \times 10^{6}$ cells $/ \mathrm{mL}$. All cell lines were diluted one day before each experiment. For differentiation into macrophages, U937 cells were treated with PMA (10 nM) and allowed to adhere for $48 \mathrm{~h}$ 
in a $5 \% \mathrm{CO}_{2}$ tissue culture incubator at $37^{\circ} \mathrm{C}$, after which they were washed and fed with PMA-free medium.

\section{Treatment with PCN and inhibitors}

PMA-differentiated U937 cells were washed and afterwards different concentrations of $\operatorname{PCN}(5,25$, and $50 \mu \mathrm{M}$ ) were added into the medium and incubated for $24 \mathrm{~h}$. Subsequently, the culture supernatant was collected and stored at $-70^{\circ} \mathrm{C}$. IL-8 concentration was measured by enzyme-linked immunosorbent assay (ELISA) assay. As a positive control, a separate group of PMAdifferentiated U937 cells was stimulated with TNF- $\alpha$ and PCN. RNA was extracted afterwards, and IL- 8 mRNA levels were determined. In some experiments, SB203580, PD98059 or PDTC was added into fresh medium of U937 cells at 60 min before PCN incubation.

\section{Thiazolyl blue tetrazolium bromide (MTT) assay}

Cell viability was assessed using the MTT assay (Sigma) according to the manufacturer's instructions.

\section{Measurement of IL-8}

Cells were cultured in 24-well tissue culture plates until they reached $80-90 \%$ confluence. Cells were cultured in serum-free medium without growth factors and medium supplements for $24 \mathrm{~h}$ prior to treatment. The medium was harvested $24 \mathrm{~h}$ after treatment and stored at $-20^{\circ} \mathrm{C}$ until assayed. IL-8 level was determined by ELISA according to the manufacturer's instructions. The reproducibility, calculated as the coefficient of variation $(\mathrm{CV})$, was $5.5 \%$.

Reverse transcription-polymerase chain reaction (RT-PCR) Total RNA was extracted from the U937 cells as described by Chomczynski [22]. At the end of the incubation period, cells were washed with $1 \mathrm{~mL}$ ice-cold PBS and solubilized with $1 \mathrm{~mL}$ of trizol. RNA was treated with chloroform, centrifuged at $12000 \times \mathrm{g}$ for $15 \mathrm{~min}$ at $4^{\circ} \mathrm{C}$ and finally precipitated with ethanol. RNA was extracted and redissolved in diethylpyrocarbonate-treated water, and the OD at $260 \mathrm{~nm}$ was used to determine its concentration. To synthesize cDNA, $2.5 \mu \mathrm{g}$ of RNA was resuspended in a $10 \mu \mathrm{L}$ final volume of the reaction buffer and incubated for $30 \mathrm{~min}$ at $42^{\circ} \mathrm{C}$. The reaction was stopped by denaturing the enzyme at $95^{\circ} \mathrm{C}$ for $5 \mathrm{~min}$. Polymerase chain reaction was performed as follows. Ten microliters of the synthesized CDNA were added to $40 \mu \mathrm{L}$ of PCR mixture containing $5 \mu \mathrm{L}$ of $5 \times$ PCR buffer, $1 \mu \mathrm{L}$ of primers (GenBank accession IL- 8 sense: 5 '-AGA TGTCAGTGCATAAAGACA-3', antisense: 5'-TGAAT TCTCAG CCCTCTTCAAAAA-3', 201 bp; GenBank accession $\beta$-actin sense: $5^{\prime}$-GGCATGGGTCAGAAGGATY CC-3', antisense: 5' -ATGTCACGCACGATTTCCCGC3', $501 \mathrm{bp}$ ) and $0.25 \mu \mathrm{L}$ DNA polymerase. PCR conditions for IL- 8 were 35 cycles of denaturation at $94^{\circ} \mathrm{C}$ for $45 \mathrm{~s}$, annealing at $55.3^{\circ} \mathrm{C}$ for $45 \mathrm{~s}$ and extension at $72^{\circ} \mathrm{C}$ for $1 \mathrm{~min}$. PCR conditions for $\beta$-actin were 35 cycles of denaturation at $94^{\circ} \mathrm{C}$ for $45 \mathrm{~s}$, annealing at $59^{\circ} \mathrm{C}$ for $45 \mathrm{~s}$ and extension at $72^{\circ} \mathrm{C}$ for $1 \mathrm{~min}$. Amplified PCR products were separated by electrophoresis on $1.5 \%$ agarose gel (UltraPure, Sigma) containing $0.05 \mu \mathrm{g} / \mathrm{mL}$ ethidium bromide. The mRNA expression was visualized using a Gel imaging system and analyzed using the molecular analyst software and was standardized by the $\beta$-actin housekeeping gene signal to correct any variability in gel loading. The ratio between the optical density of $\beta$ actin and the test gene was calculated to evaluate relative changes in the test gene.

\section{Western blotting}

The cytoplasmic and nuclear extracts from differentiated U937 cells were prepared with NEPER Nuclear and Cytoplasmic Extraction Reagents (Pierce, Rockford, IL). Equal amounts $(20 \mu \mathrm{g}$ or $10 \mu \mathrm{g}$ in the nuclear fraction) of protein extracts were electrophoresed on 8-10\% SDS polyacrylamide gels and transferred onto polyvinylidene difluoride membranes. Rabbit anti-phospho-p65 (Ser276) and p-IкB- $\alpha$ (Ser32),rabbit anti- phospho-specific p38 MAPK and p38, rabbit anti-phospho-specific ERK1/2 and ERK1/2 were used to detect the presence of phospho-p65, phospho-specific p38 MAPK and p38; phosphor-specific ERK1/2 and ERK1/2, respectively. The scanned figures were visualized and quantified using Image J software.

\section{Statistical analysis}

Data presented are representative of 3-5 independent experiments. Unless otherwise indicated, data were expressed as means \pm S.D. Data were analyzed using one-way analysis of variance followed by LSD for multiple comparisons. Differences were considered significant if $p<0.05$. All analyses were performed using SPSS 13.0 software.

\section{Results}

\section{Induction of U937 cell differentiation by PMA}

The U937 cells of a routine subculture are in the form of a single cell suspension. After $8 \mathrm{~h}$ of culture in the presence of $10 \mathrm{nM}$ PMA, the cells began to transform from flat elongated suspension cells into irregular-shaped amoeba-like cells that developed pseudopodia extensions and adhered to the bottom of the container. After $48 \mathrm{~h}$ of cultivation, $85 \%$ of the cells were adherent growth. So far, differentiation of U937 cells by treatment with PMA has been accomplished.

\section{Cell viability assay}

To assess the effect of PCN on cell viability, MTT assays were performed on cells incubated with a range of PCN concentrations $(5-100 \mu \mathrm{M})$ after $24 \mathrm{~h}$. Cell viability was 
not affected by PCN $(5-75 \mu \mathrm{M})$. Loss of cell viability by 5-6\% was observed at a PCN concentration of $100 \mu \mathrm{M}$ (data not shown). Therefore, $\mathrm{PCN}$ concentrations ranging from 5 to $50 \mu \mathrm{M}$ was used in the subsequent experiments.

\section{Effect of PCN on IL-8 mRNA}

In these studies, TNF- $\alpha$ was used as a positive control to further explore the expression of IL-8 mRNA induced by PCN. After treatments with TNF- $\alpha(10 \mathrm{ng} / \mathrm{mL})$ or PCN $(25 \mu \mathrm{M})$ alone or their combination for the indicated periods, IL- 8 mRNA levels were analyzed by RTPCR with its specific primers. PCN-mediated induction of IL-8 mRNA in differentiated U937 cells was detectable at any time point studied. TNF- $\alpha$ alone induced IL-8 mRNA in a time-dependent manner, which peaked at $2 \mathrm{~h}$, and stimulated IL- 8 release in a concentration-dependent manner after 24 hours of incubation (Figure 1). The medium alone produced trace amounts of IL-8. Treatment with PCN plus TNF- $\alpha$ slightly increased IL-8 mRNA expression. This difference, however, was not statistically significant $(p>0.05)$.

\section{Induction of IL-8 release by PCN in PMA-differentiated U937 cells}

Previous studies have identified that PCN stimulates IL8 production by lung macrophage cells [23] and surface epithelial cells $[8,14,24]$. Based on the physical properties of PCN, we hypothesized that it was able to stimulate differentiated U937 cells to produce IL-8. To test this hypothesis, we exposed differentiated human U937 cells to purified PCN and measured its effects on the release of IL-8. After 24 hours of incubation with different concentrations of PCN $(5 \mu \mathrm{M}, 25 \mu \mathrm{M}$, or $50 \mu \mathrm{M})$ in PMAdifferentiated U937cells, the supernatants were collected and IL- 8 release detected by ELISA. The results showed that PCN increased IL-8 release in differentiated U937 cells in a concentration-dependent manner. An increase in IL-8 release was observed with PCN concentration at as low as $5 \mu \mathrm{M}$ and the concentration of $50 \mu \mathrm{M}$ produced the strongest stimulation as to the cellular response (Figure 2A and B). The increase in IL-8 above control levels was observed at as early as $8 \mathrm{~h}$ after PCN $(50 \mu \mathrm{M})$ addition, and these levels continued to increase between $24 \mathrm{~h}$ and $48 \mathrm{~h}$ (data not shown). Longer periods of incubation were not tested.

\section{The oxidative effect of PCN on differentiated U937 cells}

A previous study has shown that PCN induces a concentration-dependent loss of cellular glutathione (GSH), an important cellular antioxidant, up to $50 \%$ in the tissues infected by P. aeruginosa [25]. N-acetyl cysteine (NAC) is the precursor of GSH. So we hypothesized that NAC may play a protective role in cells exposed to PCN. Thus, different concentrations of $\mathrm{PCN}$ (5, 25, and $50 \mu \mathrm{M})$ were added into differentiated U937 cells, and the supernatants were collected after 24 hours. We then detected the leakage of $\mathrm{LDH}$, the content of MDA, and the activities of SOD and CAT using their respective detection kits. Results showed that the leakage of LDH and the content of MDA increased and the activity of SOD and CAT decreased, all in a dose-dependent manner. There was a significant difference among the experimental groups $(\mathrm{p}<0.01)$ (Table 1$)$. These results indicated $\mathrm{PCN}$ can induce oxidative damage.

\section{Effects of MAPK inhibitors on PCN-induced IL-8 release}

A number of studies show that the MAPK signal transduction pathways mediate IL-8 expressions induced by a variety of stimulating factors [26]. We therefore went on to explore the possibility that PCN may induce U937

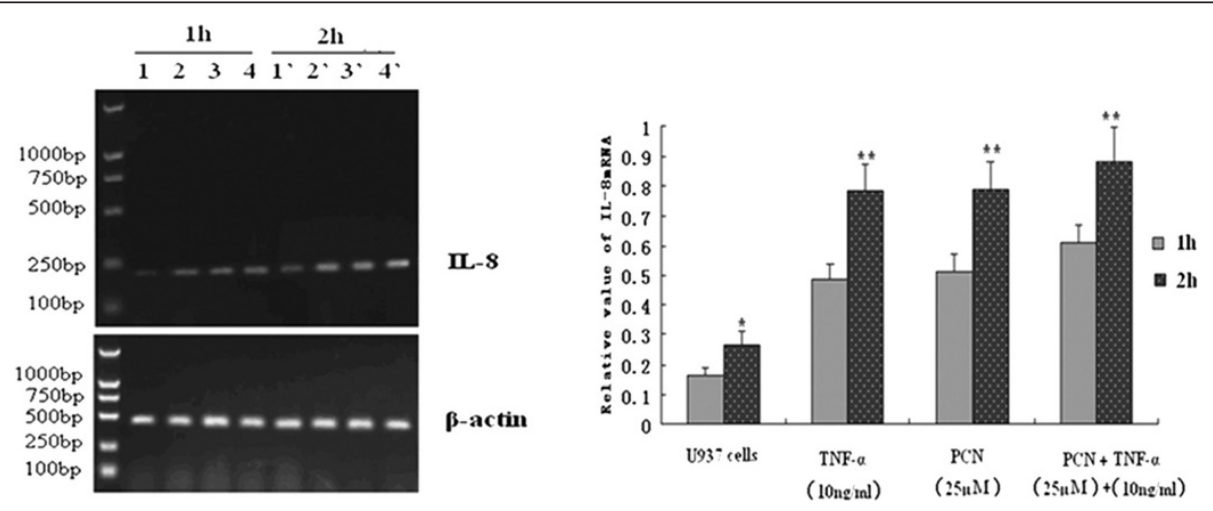

Figure 1 The expression of IL-8 mRNA in PMA-differentiated U937 cells. RNA was extracted from PMA-differentiated U937 cells after various treatments (TNF- $a$ at $10 \mathrm{ng} / \mathrm{mL}$ and PCN at $25 \mu \mathrm{M}$ and $25 \mu \mathrm{M}$ PCN combined $10 \mathrm{ng} / \mathrm{mL}$ TNF-a respectively) with the indicated time periods, and analyzed by RT-PCR with specific primers for IL-8. Results shown are representative of three separate experiments. Expression of IL-8 mRNA was quantified by densitometry, and standardized by the $\beta$-actin level. ${ }^{*} p<0.05,{ }^{* *} p<0.01$ compared with the level at $1 \mathrm{~h}$ or $2 \mathrm{~h}$. PMA: phorbol 12-myristate 13-acetate. 


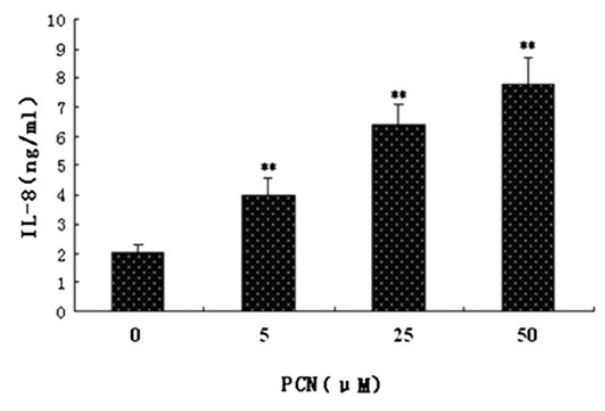

( A )

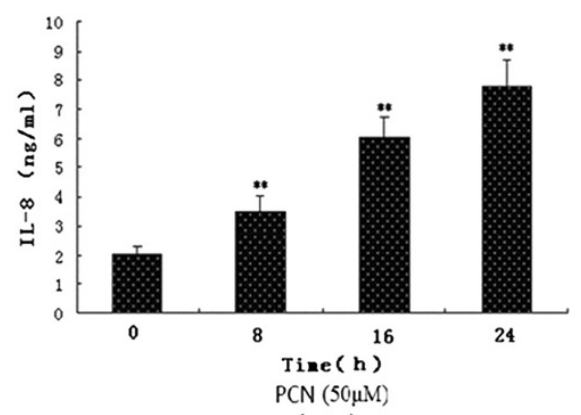

( B )

Figure 2 PCN increases IL-8 release in PMA-differentiated U937 cells. (A) Different concentrations of PCN (5 $\mu \mathrm{M}, 25 \mu \mathrm{M}$, or $50 \mu \mathrm{M})$ were added to the cell cultures for $24 \mathrm{~h}$. Supernatants were harvested for measuring IL-8 secretion by ELISA. (B) A fixed concentration of PCN (50 $\mu M$ ) was added to the cell cultures for 8,16 or $24 \mathrm{~h}$. Supernatants were harvested for measuring IL-8 level by ELISA. Values represented are the mean \pm SD of four independent experiments in triplicate. ${ }^{* *} \mathrm{p}<0.01$ compared with PMA-differentiated U937 cells. PMA: phorbol 12-myristate 13-acetate.

cells to express IL-8 through MAPK signaling. In some experiments, different concentrations of the ERK and P38 MAPK blockers (PD98059 at 10, 30, or $50 \mu \mathrm{M}$ and SB203580 at 10, 30, or $50 \mu \mathrm{M}$, respectively) were added into the fresh medium of U937 cells 60 min before PCN addition. After 24 hours, the supernatants were collected and IL- 8 concentrations were detected by ELISA. The results showed that PD98059 and SB203580 significantly decreased the secretion of IL-8, and as either substance's concentration increased, IL-8 secretion decreased, indicating that PCN may stimulate U937 cells to express IL8 by both MAPK signaling pathways (Figure 3).

\section{Effects of NF-KB inhibitor on PCN-induced IL-8 release}

To further investigate whether NF- $\mathrm{kB}$ is involved in PCN-induced IL-8 production, different concentrations of NF-kB blockers (PDTC at 50, 100, or $200 \mu \mathrm{mol} / \mathrm{L}$ ) were added into fresh medium of PMA-differentiated U937 cells 60 min before PCN was added. After 24 hours of further incubation, the supernatants were collected and IL-8 concentrations were detected. Results showed that PDTC significantly decreased the secretion of IL-8, and with increasing concentrations PDTC, IL-8 secretion decreased, although in the presence of high concentrations of $\mathrm{PCN}$, indicating that the $\mathrm{PCN}$ may stimulate PMA-differentiated U937 cells to express IL-8 by NF-kB signaling pathway (Figure 4).

\section{Effect of antioxidant on PCN-induced IL-8 release}

To further authenticate whether oxidative stress was involved in PCN-induced IL-8 production and protective role of NAC in cells exposed to PCN, different concentrations of NAC $(5,10$, or $20 \mathrm{mmol} / \mathrm{L})$ were added into fresh medium of PMA-differentiated U937 cells $60 \mathrm{~min}$ before PCN administration. After 24 hours of further incubation, supernatants were collected and IL-8 concentrations were measured. The results showed that NAC significantly decrease the secretion of IL-8, indicating a pivotal role for oxidative stress in PCN-induced IL-8 expression in PMA-differentiated U937 cells (Figure 5).

\section{Effects of MAPK and NF-KB inhibitors on PCN-induced} IL-8 mRNA

To determine whether activation of MAPK and NF- $\mathrm{kB}$ mediates the PCN-dependent increase in IL-8 mRNA, we tested the effects of several MAPK and NF- $\mathrm{BB}$ inhibitors: SB203580 (a p38 inhibitor, $30 \mu \mathrm{M}$ or $50 \mu \mathrm{M}$ ) and PD98059 (an ERK1/2 inhibitor, $30 \mu \mathrm{M}$ or $50 \mu \mathrm{M}$ ) or PDTC (an NF- $\kappa B$ inhibitor, $200 \mu \mathrm{M}$ ). For these experiments, cells were pretreated for 60 min with SB203580, PD98059, or PDTC and then stimulated for $2 \mathrm{~h}$ with $50 \mu \mathrm{M}$ PCN. The respective inhibitor was present throughout the experiments. RNA was then isolated and levels of mRNA were determined as described in materials and methods. The results showed that all blockers used can reduce the expression of IL-8 mRNA (Figure 6).

PCN increases phosphorylation of p38 and ERK1/2 MAPKs To gain direct insights into PCN effect on MAPK activation, we then used PCN $(50 \mu \mathrm{M})$ to stimulate U937 cells with or without pretreatment with MAPK inhibitors (SB 20358 or PD98059, both at $30 \mu \mathrm{M}$ ) for $1 \mathrm{~h}$. Cellular protein was collected at $0,10,30,60$, and

Table 1 The oxidative effect of pyocyanin on differentiated U937 cells

\begin{tabular}{lcccc}
\hline \multicolumn{4}{c}{$(\overline{\mathbf{x}} \pm \mathbf{s ~ n}=\mathbf{3})$} \\
\hline Group & $\mathbf{L D H}\left(\mathbf{U} \cdot \mathrm{L}^{-1}\right)$ & $\mathrm{MDA}\left(\mathrm{mmol} \cdot \mathbf{L}^{-1}\right)$ & $\mathrm{SOD}\left(\mathrm{Eu} \cdot \mathrm{mL}^{-1}\right)$ & $\mathrm{CAT}\left(\mathrm{Eu} \cdot \mathrm{mL}^{-1}\right)$ \\
\hline $\mathrm{C}_{0}$ & $301 \pm 48$ & $0.91 \pm 0.07$ & $5.99 \pm 0.96$ & $1.86 \pm 0.21$ \\
$\mathrm{C}_{1}$ & $521 \pm 48^{* *}$ & $2.01 \pm 0.23^{* *}$ & $4.66 \pm 0.75^{*}$ & $1.27 \pm 0.18^{*}$ \\
$\mathrm{C}_{2}$ & $590 \pm 52^{* *}$ & $2.93 \pm 0.19^{* *}$ & $3.86 \pm 0.62^{* *}$ & $1.01 \pm 0.14^{* *}$ \\
$\mathrm{C}_{3}$ & $668 \pm 76^{* *}$ & $3.85 \pm 0.25^{* *}$ & $3.12 \pm 0.41^{* *}$ & $0.62 \pm 0.11^{* *}$ \\
\hline
\end{tabular}

Notice: $\mathrm{C}_{0}$ : Control group; $\mathrm{C}_{1}: \mathrm{PCN}(5 \mu \mathrm{M}) ; \mathrm{C}_{2}: \mathrm{PCN}(25 \mu \mathrm{M}) ; \mathrm{C}_{3}: \mathrm{PCN}(50 \mu \mathrm{M})$. ${ }^{*} P<0.05$, compared with control; $* *<0.01$, compared with control. 


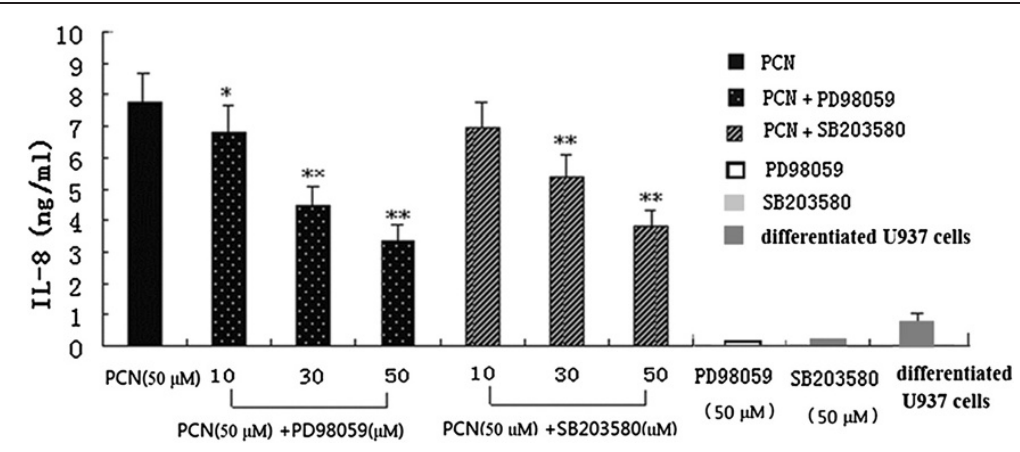

Figure 3 MAPK inhibitors attenuate PCN-induced IL-8 release. Different concentrations of the ERK or P38MAPK blockers (PD98059 at 10, 30 , or $50 \mu \mathrm{M}$ or SB203580 at 10, 30, or $50 \mu \mathrm{M}$ ) were added into fresh medium of PMA-differentiated U937 cells 60 min before PCN was added. Cells were exposed to PCN $(50 \mu \mathrm{M})$ for $24 \mathrm{~h}$. Supernatants were harvested for measuring IL-8 by ELISA. ${ }^{* *} \mathrm{p}<0.01$ compared with PMA-differentiated U937 cells. MAPK: mitogen-activated protein kinase; ERK: extracellular signal-regulated kinase; PMA: phorbol 12-myristate 13-acetate.

120 min after PCN treatment. The kinetics of p38 and ERK activation after induction were assessed by Western blotting using antibodies that specifically recognize the phosphorylated forms of p38 and ERK MAPKs. Active p38 was detected in PMA-differentiated U937 cells induced by PCN, but the activation was transient, appearing at 10 and $30 \mathrm{~min}$ and returned to baseline level after another $30 \mathrm{~min}$. Exposure of PMA-differentiated U937 cells to $\mathrm{PCN}$ for 30 min reduced activation of ERK1/2. After $30 \mathrm{~min}$ of induction, activation of ERK1/2 began to recover but then its activation was down-regulated in a time-dependent manner, while the total ERK, p38MAPK levels remained almost unchanged throughout the experimental period (Figure 7).

\section{PCN stimulated U937 cells to activate NF-KB signaling pathway}

Activation of the NF- $\mathrm{kB}$ signaling pathway is frequently involved in the regulation of many immune response and inflammatory genes [27]. To determine whether
PCN affects NF- $\mathrm{KB}$ signaling pathway, we examined the effect of PCN treatment on a series of molecular events that leads to NF- $\mathrm{kB}$ activation, including degradation of $\mathrm{I}-\mathrm{k} \mathrm{B} \alpha$ protein, translocation of $\mathrm{p} 65$ to the nucleus, and the phosphorylation of p65. We used PCN $(50 \mu \mathrm{M})$ to stimulate PMA-differentiated U937 cells. At $0,10,30,60,90$, and $120 \mathrm{~min}$, cell proteins were collected and NF- $\mathrm{kB}$ p 65 protein translocation was detected by Western blotting. As shown in Figure 8, within 10 min after addition of PCN, the level of p-I$\kappa B \alpha$ in the cytosol was increased, which returned to baseline level after $60 \mathrm{~min}$. We further investigated the change in nuclear localization of p65 protein. Within 10 min after addition of PCN, the level of p-p65 in total cell lysate and cytosol was increased. There was also an increase in the levels of p-p65 in the nuclear extract, as evidenced by high levels of p-p65 which persisted in total cell lysates (Figure 8). These results suggest that $\mathrm{PCN}$ induces degradation of $\mathrm{I}-\mathrm{kB} \alpha$ and subsequent translocation of NF- $\mathrm{kB}$ to the nucleus.

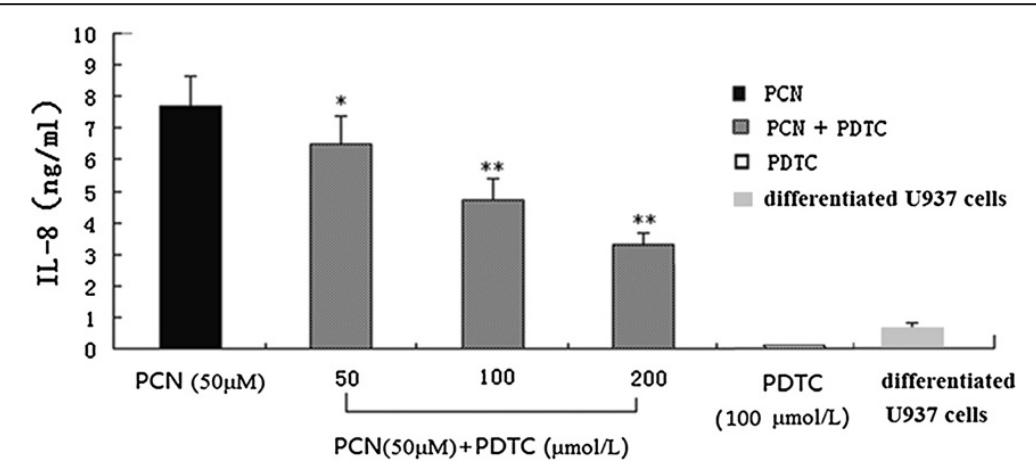

Figure 4 NF-KB inhibitor reduces PCN-induced IL-8 release. Different concentrations of NF-KB blocker (PDTC at 50, 100, or 200 $\mu \mathrm{mol} / \mathrm{L}$ ) were added into fresh medium of PMA-differentiated U937 cells 60 min before PCN was added. Cells were exposed to a fixed concentration of PCN $(50 \mu \mathrm{M})$ for $24 \mathrm{~h}$. Supernatants were harvested for measuring IL-8 by ELISA. ${ }^{*} \mathrm{p}<0.05,{ }^{* *} \mathrm{p}<0.01$ compared with the PCN group. PMA: phorbol 12-myristate 13-acetate. 


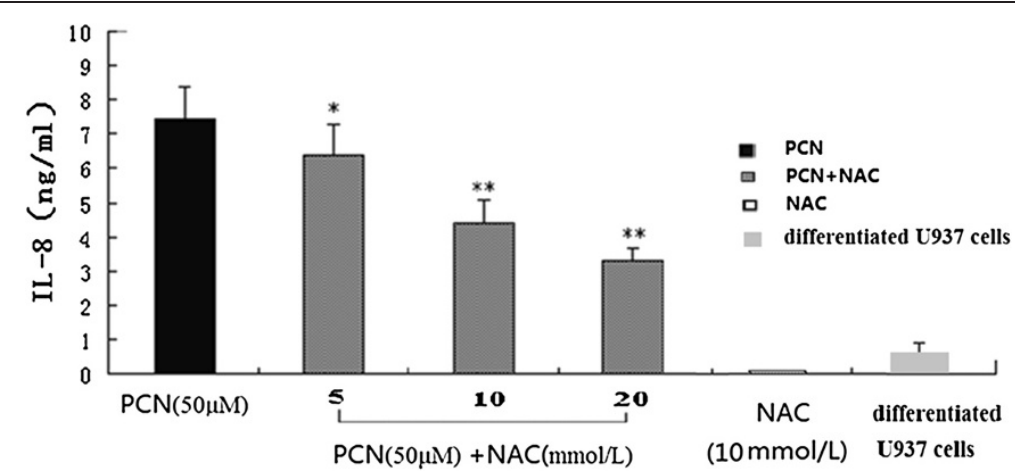

Figure 5 Antioxidant can inhibit PCN-induced IL-8 release. Different concentrations of N-acetyl cysteine (NAC) (5, 10 or 20 mM) were added into fresh medium of PMA-differentiated U937 cells for 60 min before PCN was added. After 24 h, supernatants were collected and IL-8 concentrations were detected by ELISA. ${ }^{*} p<0.05,{ }^{* *} p<0.01$ compared with the PCN groups. PMA: phorbol 12-myristate 13-acetate.

\section{Effects of MAPK inhibitors on PCN-induced NF-KB signaling activation}

To determine whether MAPKs mediate PCN-activated NF-kB signaling pathway, we used PCN $(50 \mu \mathrm{M})$ to stimulate U937 cells with or without pretreatment with MAPK and NF-kB inhibitors: SB $203580(50 \mu \mathrm{M})$, PD98059 $(50 \mu \mathrm{M})$ and PDTC $200 \mu \mathrm{M}$ for $1 \mathrm{~h}$. Cell proteins were collected at $30 \mathrm{~min}$ and NF- $\mathrm{kB}$ p65 protein translocation was detected by Western blotting. The results showed that there was abundant cytosol distribution of NF-kB p65 before stimulation. All the indicated blockers were able to reduce the localization of NF- $\mathrm{KB}$ p65 in the cytosol (Figure 9). These data suggest that SB203580 and PD98059 can effectively inhibit PCNinduced NF-KB signaling activation. Therefore, it could be concluded that the activation of p38 and ERK MAPKs are signaling events that lie upstream of NF- $\mathrm{kB}$ activation.

\section{Discussion}

The National Nosocomial Infection Surveillance indicates that $P$. aeruginosa is the second most common cause of nosocomial pneumonia after Staphylococcus aureus [28]. Ventilator-associated pneumonia (VAP) caused by $P$. aeruginosa is a severe complication of intensive care, with mortality rates of 34 to $48 \%$ [28-30]. Therefore, it is critical to study the pathogenesis of $P$. aeruginosa. In recent years, with the development of technologies such as the gene chip and the protein chip, and the clarification of the genome sequence of the $P$. aeruginosa strain, it has been found that many elements such as pro-inflammatory cytokines, antimicrobial peptides, complements and epithelial cell receptors and their signal transduction systems (TLR2, 4, 5, CFTR, GM1, and its downstream NF-kB) participate in host defense and immune response induced by $P$. aeruginosa. It has also been found that $P$. aeruginosa components
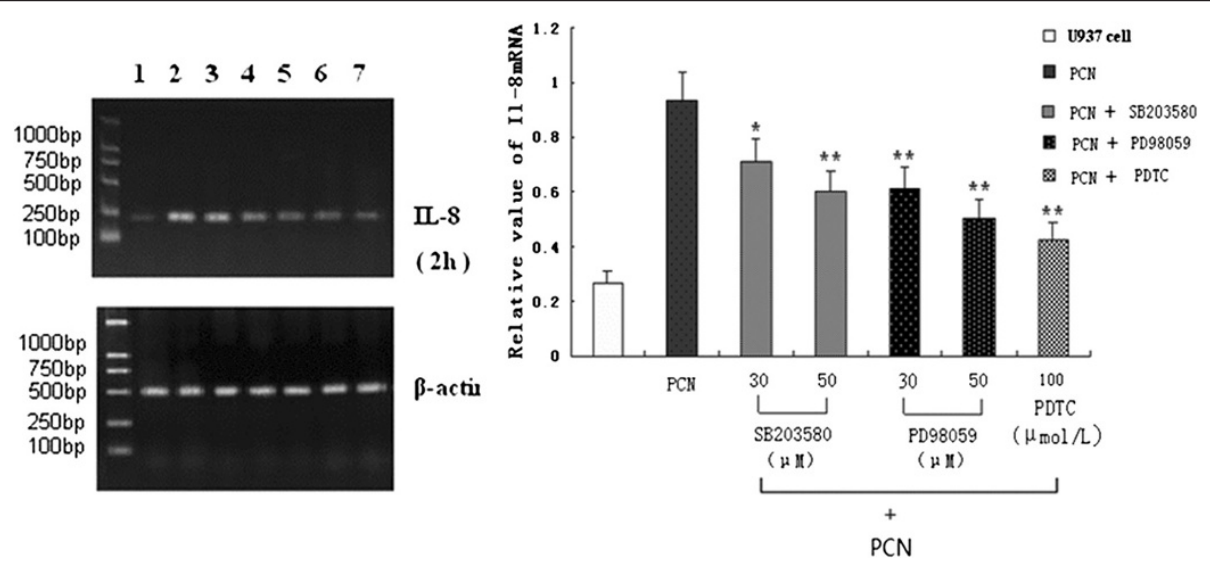

Figure 6 MAPKs and NF-KB inhibitors can attenuate PCN-induced IL-8 mRNA. PMA-differentiated U937 cells were pretreated for 60 min with SB203580 (30 $\mu \mathrm{M}$ or $50 \mu \mathrm{M})$, PD98059 $(30 \mu \mathrm{M}$ or $50 \mu \mathrm{M})$ or PDTC $(200 \mu \mathrm{M})$ and then stimulated for $2 \mathrm{~h}$ with $50 \mu \mathrm{M}$ PCN. Inhibitors were present throughout. RNA was then isolated, and levels of mRNA were determined. Expression of IL-8 mRNA was quantified by densitometry and standardized by $\beta$-actin. ${ }^{*} p<0.05,{ }^{* *} p<0.01$ compared with PCN. MAPK: mitogen-activated protein kinase; PMA: phorbol 12-myristate 13-acetate. 
(flagella and pili) and virulence factors (such as the density-sensing system, type secretion system, toxins, alginate and cell toxin) play important roles in the pathogenesis $[2,16]$. Among them, most $P$. aeruginosa strains secrete PCN (N-methyl-1-hydroxyphenazine), the pigment that gives blue-green color to the bacterial colonies [4]. High concentrations of PCN are detected in pulmonary secretions of patients with cystic fibrosis, where it triggers inflammation, disrupts the bronchial epithelium and impairs ciliary function. PCN also interferes with the antioxidant defenses in the lung and facilitates oxidative damage to the lung epithelium [31-35]. PCN has been detected at concentrations as high as $100 \mu \mathrm{M}$ in pulmonary secretions from patients with $P$. aeruginosa-associated airway disease [36], and its production is increased when the organism is in the biofilm form
[4,37]. Therefore, PCN plays an important role in acute and chronic invasive infections.

Pseudomonas infections are characterized by a marked influx of polymorphonuclear cells (PMNs) (neutrophils) [12]. Activated PMNs release a variety of oxidants and proteases that may contribute to the tissue injury that is observed in Pseudomonas-infected airways [12,38]. Little is known about the stimuli that are responsible for the influx and activation of PMNs into the presence of this bacterium. IL-8 is the major PMN chemoattractant responsible for PMN influx and activation in a variety of disease states and thus likely plays an important role in $P$. aeruginosa infections as well. It has been found that culture supernatants and various purified secretion factors of $P$. aeruginosa such as pili protein, flagellin, selfsensing materials, elastase, $\mathrm{PCN}$ and nitrite reductase 


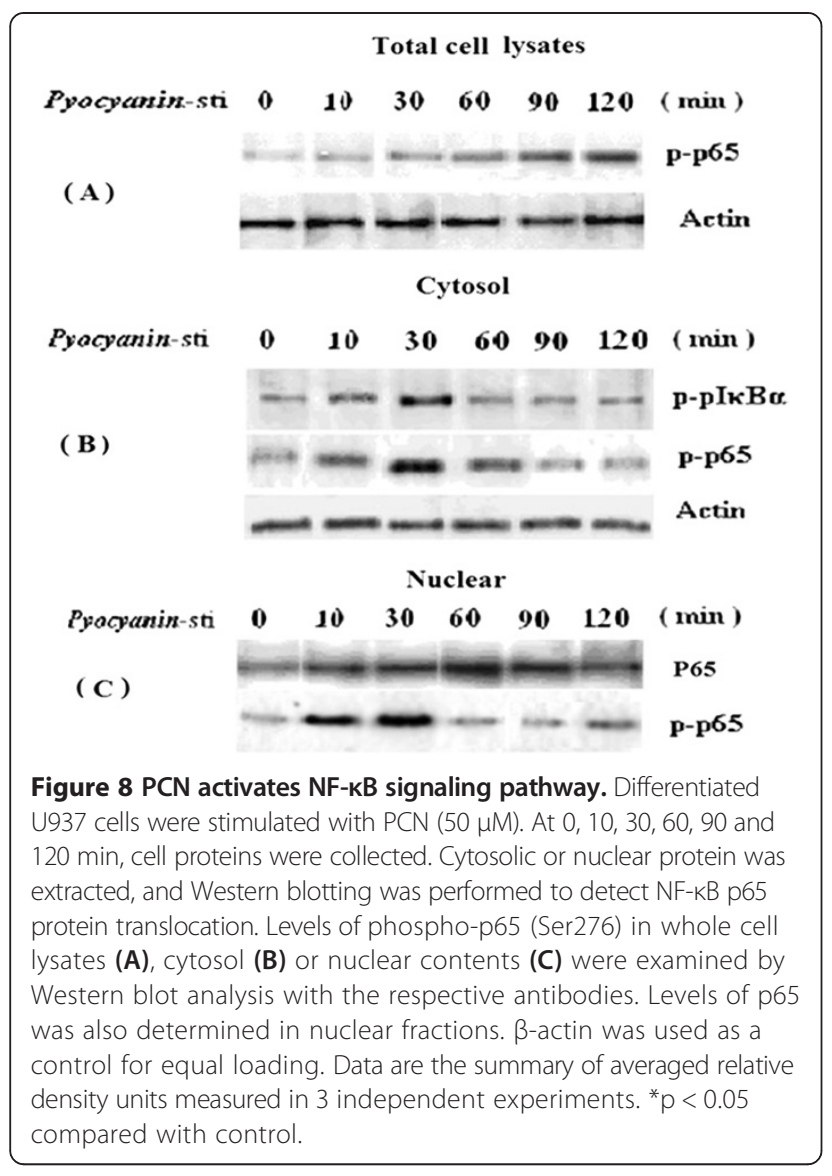

$[4,13,36,39,40]$ increase IL- 8 secretion in airway epithelial cells, primary bronchial gland epithelial cells both in vivo and in vitro [40]. It was found that with NF- $\mathrm{kB}$ activation, rapid and sustained IL-8 mRNA expression was induced [37].

Recent studies have also further confirmed that in a variety of respiratory cell lines and primary cultures of cells, PCN stimulation can cause the release of IL-8, accompanied by increased IL- 8 mRNA expression. PCN also acts in synergy with IL- $1 \alpha, \mathrm{IL}-1 \beta$ and TNF- $\alpha$ to

\begin{tabular}{|c|c|c|c|c|c|c|}
\hline pyocyanin & $1-$ & + & + & + & + & (30min) \\
\hline SB203580 & $0-$ & - & - & - & + & \\
\hline PD98059 & - & - & + & - & - & \\
\hline \multirow[t]{3}{*}{ PDTC } & - & - & - & + & - & \\
\hline & $\overline{-}$ & - & $=$ & 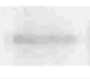 & - & $\begin{array}{r}\text { p-p65(Ser276) } \\
\text { (cytosol) }\end{array}$ \\
\hline & $=0$ & - & $=0$ & *nie & $\cos$ & Actin (cytosol) \\
\hline \multicolumn{7}{|c|}{$\begin{array}{l}\text { Figure } 9 \text { Effects of MAPK inhibitors on PCN-induced NF-KB } \\
\text { signaling pathway. U937 cells were stimulated with PCN at } 50 \mu \mathrm{M} \\
\text { for the time periods indicated with or without pretreatment by } \\
\text { MAPK and NF-KB inhibitors: SB } 203580(50 \mu \mathrm{M}) \text {, PD98059 }(50 \mu \mathrm{M}) \\
\text { and PDTC }(200 \mu \mathrm{M}) \text { for } 1 \mathrm{~h} \text {. Cell proteins were then collected and } \\
\text { NF-KB p65 protein expression was detected with Western blotting. }\end{array}$} \\
\hline
\end{tabular}

induce IL-8 expression [5,6,8]. After PCN was injected into animals and the respiratory tracts, bronchial lavage fluid and neutrophil (PMN) levels were increased significantly [41]. However, there are few reports on PCN effect on macrophages.

Our experimental results show that PCN induced expression of IL-8 in PMA-differentiated U937 cells, as well as IL-8 protein secretion and mRNA expression in a concentration- and time- dependent manner. It is also found that PCN synergizes with TNF- $\alpha$ to induce the expression of IL-8 in PMA-differentiated U937 cells. So far, most studies only observe the pro-inflammatory effects of the $P$. aeruginosa bacterial products on epithelial cells and macrophages, and their effects on U937 cells are less than well defined. The present study extends these findings by demonstrating that MAPKs and NF- $\mathrm{kB}$ signalings lie behind PCN-induced IL-8 production in differentiated U937 cells.

The MAPK family has an important role in signal transduction, and the pathway is activated by a variety of stimuli such as growth factors and cellular stresses $[42,43]$. Activated MAPKs can regulate the expression of inflammatory cytokines. In mammalian cells, it has been found that there are at least three major MAP kinase (MAPK) pathways including the extracellular signal-regulated kinase pathway (ERK), c-Jun N-terminal kinase/stress-activated protein kinase pathway (JNK), and the P38 MAPK pathway. A unique feature of the MAPKs is that they become activated after phosphorylation of both their tyrosine and threonine amino acids [44]. They are different activated extracellular signals that produce different biological effects. It has been found that MAPKs can modulate the expression of IL-8 in human peripheral blood mononuclear cells, granulocytes, mast cells, intestinal epithelial cells, and pulmonary vascular endothelial cells and that the use of P38 inhibitors can reduce the IL-8 mRNA and protein expression $[19,23,41,45]$.

We used PCN to stimulate PMA-differentiated U937 cells and found that PCN could induce ERK and P38 MAPK protein phosphorylation, thus indicating the possible participation of ERK and p38 MAPK pathways in the regulation of IL-8. Our further investigation using MAPK pathway inhibitors PD98059 and SB203580 demonstrated that they may partially inhibit the phosphorylation and reduce IL- 8 synthesis induced by PCN in a concentration-dependent manner, indicating that PCN may stimulate PMA-differentiated U937 cells to express cytokine IL- 8 by MAPK signaling pathways.

NF- $\mathrm{kB}$ is a ubiquitous pleiotropic transcription factor, and studies have shown that NF-kB activation is critically involved in a variety of lung diseases and lung inflammation [19-21]. NF-kB activation can regulate a series of lung gene expression related to inflammatory and immune responses: pro-inflammatory cytokines such as TNF- $\alpha$, IL- 
$1 \beta$, chemokines MCP-1, IL-8, and many other molecules. Therefore, its activity is closely related with acute lung injury (ALI) and acute respiratory distress syndrome (ARDS) [46]. In most cell types, NF-kB is retained usually in the cytoplasm of the unstimulated cells by $\mathrm{I}-\mathrm{kB} \alpha$ family proteins. Upon stimulation, the I- $\mathrm{kB} \alpha$ kinase complex is activated, resulting in the phosphorylation of I-kBs $[47,48]$ The phosphorylated IkBs are ubiquitinated and subsequently degraded, which will release the transcription factor NF-kB [36,37]. In this study, we also found that PCN stimulation was associated with a significant increase in the level of phosphorylated I-kB $\alpha$ in total cell lysates. We further demonstrated that I-kB $\alpha$ decrease was accompanied by increased nuclear localization of $\mathrm{p} 65$ protein. These results suggest that $\mathrm{PCN}$ induces degradation of $\mathrm{I}-\mathrm{kB} \alpha$ and the subsequent translocation of NF- $\mathrm{kB}$ to the nucleus. The results also showed that different blockers (SB203580, PD98059 and PDTC) can reduce the expression of NF-kB p65 expression in cytosol and IL-8 expression, indicating that PCN may stimulate PMA-differentiated U937 cells to express cytokines IL- 8 by MAPK and NF- $\mathrm{BB}$ signaling pathways.

Acute and chronic pulmonary infection with $P$. aeruginosa is associated with an intense neutrophil inflammatory response that contributes to lung injury [49]. A previous study has shown that PCN enhances airway epithelial cell release of IL-8 [4], a neutrophil chemokine whose production is regulated by oxidant-sensitive transcription factors [50,51]. Our data indicated that PCN could induce oxidative damage in U937 cells and antioxidant NAC inhibited PCN-induced IL-8 protein expression. In most cases, PCN's cytotoxicity has been strongly linked to its potential effects on redox cycle. When entering into cells, PCN oxidizes intracellular pools of NADPH, $\mathrm{NADH}$ and GSH directly by accepting electrons, and it passes these electrons to oxygen leading to sustained generation of $\operatorname{ROS}\left(\mathrm{O}_{\overline{2}}\right.$ and $\left.\mathrm{H}_{2} \mathrm{O}_{2}\right)$ under aerobic condition [25]. Oxidative damage results in unbalance between the oxidant and antioxidant processes. Antioxidant defense system (enzymatic scavengers SOD, CAT and so on and some smal1 molecule antioxidants including NAC, GSH, vitamin $\mathrm{C}$ and vitamin $\mathrm{E}$ ) plays an important role in the elimination of oxygen radical [52]. Cellular GSH levels have been reported to influence the activity of a number of transcription factors, including NF- $\mathrm{kB}, \mathrm{AP}-1$, and HIF$1 \alpha[53,54]$. NAC is a thiol compound that has direct antioxidant properties and also is converted to GSH by cells and thereby limits oxidant-mediated cell injury. By demonstrating the inhibitory effect of NAC on PCN-induced IL-8 production, we indicate that NAC can act as a protective factor that mitigates $\mathrm{PCN}$ pro-inflammatory effect on differentiated U937 cells.

In short, in this study, we found that PCN could induce PMA-differentiated U937 cells to produce IL- 8 by activating MAPKs and NF- $\mathrm{KB}$ signaling pathways. Our further studies will focus on understanding the interaction between p38 MAPK, ERK and other cytokine regulators. Knowledge of the mechanisms by which PCN induces PMA-differentiated U937 cells to produce cytokines may provide better understanding and rational approaches for the control of $\mathrm{PCN}$-induced inflammatory processes.

\section{Conclusions}

PCN induces U937 cells in a concentration- and timedependent manner to increase IL-8 mRNA expression and secretion. Furthermore, MAPKs and NF- $\mathrm{kB}$ signaling pathways may be involved in the expression of IL-8 in PCN-exposed U937 cells, indicating that the green pus streptozotocin in the P.aeruginosa infection has an important role in inflammation reactions. PCN or TNF$\alpha$ alone could induce PMA-differentiated U937 cells to express IL-8, but no synergistic effect was observed between these two factors. The mechanism requires further study.

\section{Competing interests}

The authors declare that they have no competing interests.

\section{Authors' contributions}

WC made substantial contributions to conception and design of this work. $J Z$ and YD drafted the manuscript. WL and YL revised it critically for important intellectual content. $X Y$ and $W L$ were responsible for the experimental operation. DP carried out the analysis and interpretation of the data. BC made final approval of the version to be published. All authors read and approved the final manuscript.

\section{Acknowledgments}

The authors gratefully acknowledge the technical advice and assistance of Dr. HongXin Wang, Dr. RongJian Su, and Mr. ZhiHong Zong. This study was partially funded by the Department of Science and Technology in Liaoning province (No. 201102126) and Liaoning Medical University (No.XZJJ20130105-02).

\section{Author details}

${ }^{1}$ Department of Respiratory Diseases, the First Affiliated Hospital of Liaoning Medical University, Jinzhou, Liaoning, 121001, China. ${ }^{2}$ Hebei Medical University, Shijiazhuang, Hebei 050000, China. ${ }^{3}$ Department of Infectious Diseases, the First Affiliated Hospital of China Medical University, Shenyang, Liaoning 110001, China.

Received: 20 November 2013 Accepted: 3 February 2014 Published: 6 February 2014

\section{References}

1. Aloush V, Navon-Venezia S, Seigman-Igra Y, Cabili S, Carmeli Y: Multidrug-resistant Pseudomonas aeruginosa: risk factors and clinical impact. Antimicrob Agents Chemother 2006, 50(1):43-48.

2. Sadikot RT, Blackwell TS, Christman JW, Prince AS: Pathogen-host interactions in Pseudomonas aeruginosa pneumonia. Am J Respir Crit Care Med 2005, 171(11):1209-1223.

3. Shanks KK, Guang W, Kim KC, Lillehoj EP: Interleukin-8 production by human airway epithelial cells in response to Pseudomonas aeruginosa clinical isolates expressing type a or type b flagellins. Clin Vaccine Immunol 2010, 17(8):1196-1202.

4. Denning GM, Wollenweber LA, Railsback MA, Cox CD, Stoll LL, Britigan BE: Pseudomonas pyocyanin increases interleukin-8 expression by human airway epithelial cells. Infect Immun 1998, 66(12):5777-5784.

5. Rada B, Gardina P, Myers TG, Leto TL: Reactive oxygen species mediate inflammatory cytokine release and EGFR-dependent mucin secretion in 
airway epithelial cells exposed to Pseudomonas pyocyanin. Mucosal Immunol 2011, 4(2):158-171.

6. Look DC, Stoll LL, Romig SA, HumLicek A, Britigan BE, Denning GM: Pyocyanin and its precursor phenazine-1-carboxylic acid increase IL-8 and intercellular adhesion molecule- 1 expression in human airway epithelial cells by oxidant-dependent mechanisms. J Immunol 2005, 175(6):4017-4023.

7. Matsushima K, Baldwin ET, Mukaida N: Interleukin-8 and MCAF: novel leukocyte recruitment and activating cytokines. Chem Immunol 1992, 51:236-265

8. Pan NY, Hui WS, Tipoe GL, Taylor GW, Leung RY, Lam WK, Tsang KW, Mak JC: Inhibition of pyocyanin-potentiated IL-8 release by steroids in bronchial epithelial cells. Resp Med 2006, 100(9):1614-1622.

9. Huang ZL, Failla ML: Copper deficiency suppresses effector activities of differentiated U937 cells. J Nutr 2000, 130:1536-1542.

10. Harris P, Ralph P: Human leukemic models of myelomonocytic development: a review of the HL-60 and U937 cell lines. J Leukocyte Biol 1985, 37:407-422.

11. Hewison M, Brennan A, Singh-Ranger R, Walters JC, Katz DR, O'Riordan JL: The comparative role of 1,25-dihydroxycholecalciferol and phorbol esters in the differentiation of the U937 cell line. Immunology 1992, 77:304-311.

12. Miller RA, Britigan BE: The formation and biologic significance of phagocyte-derived oxidants. J Invest Med 1995, 43(1):39-49.

13. Oishi K, Sar B, Wada A, Hidaka Y, Matsumoto S, Amano H, Sonoda F, Kobayashi S, Hirayama T, Nagatake T, et al: Nitrite reductase from Pseudomonas aeruginosa induces inflammatory cytokines in cultured respiratory cells. Infect Immun 1997, 65(7):2648-2655.

14. Massion PP, Inoue H, Richman-Eisenstat J, Grunberger D, Jorens PG, Housset B, Pittet JF, Wiener-Kronish JP, Nadel JA: Novel Pseudomonas product stimulates interleukin-8 production in airway epithelial cells in vitro. J Clin Invest 1994, 93(1):26-32.

15. Guha M, Mackman N: LPS induction of gene expression in human monocytes. Cell Signal 2001, 13(2):85-94.

16. Li J, Kartha S, lasvovskaia S, Tan A, Bhat RK, Manaligod JM, Page K, Brasier AR, Hershenson MB: Regulation of human airway epithelial cell IL-8 expression by MAP kinases. Am J Physiol Lung Cell Mol Physiol 2002, 283(4):L690-L699.

17. Tang H, Sun Y, Shi Z, Huang H, Fang Z, Chen J, Xiu Q, Li B: YKL-40 induces IL-8 expression from bronchial epithelium via MAPK(JNK and ERK) and NF-kB pathways,causing bronchial smooth muscles proliferation and migration. J Immunol 2013, 190:428-446.

18. Bhattacharyya S, Gutti U, Mercado J, Moore C, Pollard HB, Biswas R: MAPK signaling pathways regulate IL-8 mRNA stability andIL-8 protein expression in cystic fibrosis lung epithelial cell lines. Am J Physiol Lung Cell Mol Physiol 2011, 300:L81-L87.

19. Feoktistov I, Goldstein AE, Biaggioni I: Role of p38 mitogen-activated protein kinase and extracellular signal-regulated protein kinase kinase in adenosine A2B receptor-mediated interleukin- 8 production in human mast cells. Mol Pharmacol 1999, 55(4):726-734.

20. Hobbie S, Chen LM, Davis RJ, Galan JE: Involvement of mitogen-activated protein kinase pathways in the nuclear responses and cytokine production induced by Salmonella typhimurium in cultured intestinal epithelial cells. J Immunol 1997, 159(11):5550-5559.

21. Raia V, Maiuri L, Ciacci C, Ricciardelli I, Vacca L, Auricchio S, Cimmino M, Cavaliere M, Nardone M, Cesaro A, et al: Inhibition of p38 mitogen activated protein kinase controls airway inflammation in cystic fibrosis. Thorax 2005, 60(9):773-780.

22. Chomczynski P: A reagent for the single-step simultaneous isolation of RNA, DNA and proteins from cell and tissue samples. BioTechniques 1993, 15(3):532-534. 536-537.

23. Lauredo IT, Sabater JR, Ahmed A, Botvinnikova Y, Abraham WM Mechanism of pyocyanin- and 1-hydroxyphenazine-induced lung neutrophilia in sheep airways. J Appl Physio/ 1998, 85(6):2298-2304.

24. Denning GM, lyer SS, Reszka KJ, O'Malley Y, Rasmussen GT, Britigan BE: Phenazine-1-carboxylic acid, a secondary metabolite of Pseudomonas aeruginosa, alters expression of immunomodulatory proteins by human airway epithelial cells. Am J Physiol Lung Cell Mol Physiol 2003, 285(3):L584-L592.

25. O'Malley YQ, Reszka KJ, Spitz DR, Denning GM, Britigan BE: Pseudomonas aeruginosa pyocyanin directly oxidizes glutathione and decreases its levels in airway epithelial cells. Am J Physiol Lung Cell Mol Physiol 2004, 287:L94-L103.

26. Sémiramoth N, Gleizes A, Turbica I, Sandré C, Gorges R, Kansau I, Servin A, Chollet-Martin S: Escherichia coli type 1 pili trigger late IL-8 production by neutrophil-like differentiated PLB-985 cells through a Src family kinase- and MAPK-dependent mechanism. J Leukoc Biol 2009, 85:310-321.

27. Chen LF, Greene WC: Shaping the nuclear action of NFkappaB. Nat Rev Mol Cell Biol 2004, 5:392-401.

28. National Nosocomial Infections Surveillance System: National Nosocomial Infections Surveillance (NNIS) System report, data summary from January 1992 through June 2003. Am J Infect Control 2003, 31:481-498.

29. Cook DJ, Walter SD, Cook RJ, Griffith LE, Guyatt GH, Leasa D, Jaeschke RZ, Brun-Buisson C: Incidence and risk factors for ventilator associated pneumonia in critically ill patients. Ann Intern Med 1998, 129:433-440.

30. American Thoracic Society: Hospital-acquired pneumonia in adults: diagnosis, assessment of severity, initial antimicrobial therapy and preventive strategies. A consensus statement. American Thoracic Society. Am J Respir Crit Care Med 1996, 153:1711-1725.

31. Elswaifi SF, Palmieri JR, Hockey KS, Rzigalinski BA: Antioxidant nanoparticles for control of infectious disease. Infect Disord Drug Targets 2009, 9(4):445-452.

32. O'Malley YQ, Abdalla MY, McCormick ML, Reszka KJ, Denning GM, Britigan BE: Subcellular localization of Pseudomonas pyocyanin cytotoxicity in human lung epithelial cells. Am J Physiol Lung Cell Mol Physiol 2003, 284(2):L420-L430.

33. O'Malley YQ, Reszka KJ, Rasmussen GT, Abdalla MY, Denning GM, Britigan BE: The Pseudomonas secretory product pyocyanin inhibits catalase activity in human lung epithelial cells. Am J Physiol Lung Cell Mol Physiol 2003, 285(5): L1077-L1086.

34. Rada B, Lekstrom K, Damian S, Dupuy C, Leto TL: The Pseudomonas toxin pyocyanin inhibits the dual oxidase-based antimicrobial system as it imposes oxidative stress on airway epithelial cells. J Immunol 2008, 181(7):4883-4893.

35. Rada B, Leto TL: Redox warfare between airway epithelial cells and Pseudomonas: dual oxidase versus pyocyanin. Immunol Res 2009, 43(1-3):198-209.

36. Shibata Y, Nakamura H, Kato S, Tomoike H: Cellular detachment and deformation induce IL-8 gene expression in human bronchial epithelial cells. J Immunol 1996, 156(2):772-777

37. Scheid P, Kempster L, Griesenbach U, Davies JC, Dewar A, Weber PP, Colledge WH, Evans MJ, Geddes DM, Alton EW: Inflammation in cystic fibrosis airways: relationship to increased bacterial adherence. Eur Respir J 2001, 17(1):27-35.

38. Lau GW, Hassett DJ, Britigan BE: Modulation of lung epithelial functions by Pseudomonas aeruginosa. Trends Microbiol 2005, 13(8):389-397.

39. DiMango E, Zar HJ, Bryan R, Prince A: Diverse Pseudomonas aeruginosa gene products stimulate respiratory epithelial cells to produce interleukin-8. J Clin Invest 1995, 96(5):2204-2210.

40. Leidal KG, Munson KL, Denning GM: Small molecular weight secretory factors from Pseudomonas aeruginosa have opposite effects on IL-8 and RANTES expression by human airway epithelial cells. Am J Resp Cell Mol Biol 2001, 25(2):186-195.

41. Joseph T, Look D, Ferkol T: NF-kappaB activation and sustained IL-8 gene expression in primary cultures of cystic fibrosis airway epithelial cells stimulated with Pseudomonas aeruginosa. Am J Physiol Lung Cell Mol Physiol 2005, 288(3):L471-L479.

42. Davis RJ: The mitogen-activated protein kinase signal transduction pathway. J Biol Chem 1993, 268(20):14553-14556.

43. Kyriakis JM, Avruch J: Sounding the alarm: protein kinase cascades activated by stress and inflammation. J Biol Chem 1996, 271(40):24313-24316.

44. Mancuso G, Midiri A, Beninati C, Piraino G, Valenti A, Nicocia G, Teti D, Cook J, Teti G: Mitogen-activated protein kinases and NF-kappa B are involved in TNF-alpha responses to group B streptococci. J Immunol 2002, 169(3):1401-1409.

45. Zu YL, Qi J, Gilchrist A, Fernandez GA, Vazquez-Abad D, Kreutzer DL, Huang CK, Sha'afi Rl: p38 mitogen-activated protein kinase activation is required for human neutrophil function triggered by TNF-alpha or FMLP stimulation. J Immunol 1998, 160(4):1982-1989.

46. Nathens AB, Bitar R, Davreux C, Bujard M, Marshall JC, Dackiw AP, Watson RW Rotstein OD: Pyrrolidine dithiocarbamate attenuates endotoxin-induced acute lung injury. Am J Resp Cell Mol Biol 1997, 17(5):608-616.

47. Hayden MS, Ghosh S: Shared principles in NF-kB signaling. Cell 2008, 132:344-362.

48. Sun SC, Ley SC: New insights into NF-kB regulation and function. Trends Immunol 2008, 29:469-478

49. Fick RB Jr, Hata JS: Pathogenetic mechanisms in lung disease caused by Pseudomonas aeruginosa. Chest 1989, 95:206S-213S. 
50. Pinkus $R$, Weiner $L M$, Daniel V: Role of oxidants and antioxidants in the induction of AP-1, NF-kappaB, and glutathione S-transferase gene expression. J Biol Chem 1996, 271:13422-13429.

51. Remick DG, Villarete L: Regulation of cytokine gene expression by reactive oxygen and reactive nitrogen intermediates. J Leukoc Biol 1996, 59:471-475.

52. Olsvik PA, Kristensen $T$, Waagbø R, et al: mRNA expression of antioxidant enzymes(SOD,CAT and GSH-Px)and lipid peroxidative stress in liver of Atlantic salmon fSalmo salar)exposed to hyperoxic water during smoltification. Comp Biochem Physiol C Toxicol Pharmaco 2005, 141:314-323.

53. Semenza GL: HIF-1, $\mathrm{O}_{2}$, and the 3 PHDs: how animal cells signal hypoxia to the nucleus. Cell 2001, 107:1-3.

54. Sauer $H$, Wartenberg $M$, Hescheler J: Reactive oxygen species as intracellular messengers during cell growth and differentiation. Cell Physiol Biochem 2001, 11:173-186.

doi:10.1186/1471-2180-14-26

Cite this article as: Chai et al:: Pseudomonas pyocyanin stimulates IL-8 expression through MAPK and NF-KB pathways in differentiated U937 cells. BMC Microbiology 2014 14:26.

\section{Submit your next manuscript to BioMed Central and take full advantage of:}

- Convenient online submission

- Thorough peer review

- No space constraints or color figure charges

- Immediate publication on acceptance

- Inclusion in PubMed, CAS, Scopus and Google Scholar

- Research which is freely available for redistribution 